wetted by water. This no doubt arises, partly at least, from the condensation of gases on the surface, which Quincke has shown will produce this effect to a remarkable extent under certain conditions described by him. To this, also, Barrett and Stoney have referred certain modifications of Leidenfrost's phenomena ; and the floating shells, \&c., of Hennessey are due to the same general cause. But a very minute trace of oil on a physically clean surface produces the familiar greasy surface. Why is this? Oil is not insoluble in water, and when the quantity of water used is sufficient to dissolve the quantity of oil placed on the glass, it ought to wash off. Every one knows, however, how difficult it is to wash oil off glass. Is this then due to a diminution in the solubility of the oil in the water owing to its CONDENSATION on the glass surface? I believe it to be very probable that this is the case, and think that the experimental proof would be possible by placing estimated quantities of oil on a physically clean glass surface, and subsequently washing in quantities of water, such as under ordinary circumstances would readily suffice to dissolve it. By dissolving the oil in a volatile medium, its quantity might be readily estimated. No doubt other liquids of somewhat greater and better known solubility might be advantageously substituted for the oil, and perhaps, as Dr. Japp has suggested to me, by employing a coloured liquid the result might be rendered evident to the eye.

My inability to complete these experiments at the present time, and the great interest attaching to a determination as to whether the condensation experienced by the liquid-film alters the physical or chemical properties of the liquid must be the excuse for the publication of incomplete results, which I much hope may be taken up by others.

J. W. CLARK

\section{THE STOCKHOLM ETHNOGRAPHICAL EXHIBITION}

D

R. STOLPE was asked to arrange and describe the Ethnographical Exhibition of Stockholm in the year 1878 . This exhibition was brought together from all, or at least nearly all, Swedish public and private collections; no less than 217 exhibitors with about 10,000 objects participated, the King himself opened the galleries, and general interest was raised by an ethnographical exhibition as indeed no other country has realised till now. We took occasion to visit the exhibition, and were astonished to see so rich a material, as well as a thoroughly scientific arrangement.

Both works named below are a result of the meritorious undertaking. The second was partly a guide through some parts of the exhibition, especially China and Japan, with a general introduction, and many valuable and interesting special remarks, partly, in its second volume, a determination of all, about 6200 numbers of the exhibition, arranged after the exhibitors. The first-named work illustrates in geographical order the more important objects of the exhibition, partly in groups, but chiefly in single representations. There may be represented in all about I 500 objects, and we hear that a fourth supplementary volume is in the press.

The first volume of this album contains, on 84 plates, Australia, Oceania, Malaysia, Madagascar, Malayo-Chinese, and Tibet; the second, on 116 plates, China, Japan, Samoyedes, and Turks; the third, on 78 plates, America, Africa, Circassia, Persia, and India. Japan and China, as well as Oceania, are relatively best represented; among the last-named division figures the fine collection from the Savage Islands, which the expedition of the Eugenie brought home in the year 1853 .

r H. Stolpe, "Exposition ethnographique de Stockholm, 1878-r879." Photographies par L. F. Lindberg. 3 vols. 4to. 36 pp. $27^{8}$ plates. (Stockholm, 188r).- "Den allmänna etnografiska utställingen, 1878-1879" (The General Ethnographical Exhibition). 2 vols. 8 vo. 80 pp. 1878-1879, and viii. II2 pp. 1880 .
This photographic album must be regarded as the best existing ethnographical atlas; it gives, notwithstanding the inequality in the representation of the single countries, a good idea of a high-class ethnographical museum. The editor has had a full appreciation of the problem which was to be solved, and no ethnologist who works scientifically can do well without this album. It was therefore right that the International Geographical Congress of Venice in the year $188 \mathrm{I}$ should bestow a prize on this beautiful work. Copies of the album are, we believe, only printed to order, and may be obtained direct from Herr Lindberg, R. Archæological Museum, Stockholm.

\section{A. B. MEYer}

\section{BARON MIKLOUHO-MACLAY}

ETTERS have been received from Baron $N$. de Mikloubo-Maclay from the Suez Canal, the distinguished traveller being now on his way back to Australia. During his prolonged and arduous experience of eleven years' life amongst Melanesian and other savages of the Pacific his health has, we are sorry to say, suffered very seriously, and he returns to Sydney mainly on this account, since he finds that the climate of New South Wales suits him best. He intends to call at Batavia on the way out, where he left a part of his collections in 1878 , in order to convey these to Sydney, where the main bulk of the gatherings of his many journeys is already stored. The Emperor of Russia, with enlightened liberality, has promised to defray the cost of the publication of the scientific account of Baron de Maclay's results, and the collections have been brought together at Sydney in order that they may be available for the preparation of the work for the press there.

Baron de Maclay hopes to be able to get ready the whole of his numerous diaries, notes, and papers for publication in about two years' time. The complete work to be issued by him will, if his present plan be carried out, consist of an anthropological and ethnographical section, a section treating of comparative anatomy, and a general narrative of his travels, together with appendices containing meteorological observations and information on physical geography.

The work will be published first in Russian, but translations in other languages will probably soon follow.

He intends to do a good deal of the anatomical work needed to complete his researches on animals collected by him in Australia and New Guinea at the Zoological Station at Watson's Bay, of which he is the founder. This Zoological Laboratory at the very first received most important support from the Linnean Society of New South Wales, and by the influence of this Society a grant of land was obtained from the Ne:v South Wales Government for the erection of the building. Scientific men in other colonies, and notably in Victoria, recognising the great imporiance of the establishment to the progress of biological research, have come forward nobly to support the enterprise, and the Australian Biological Association has been formed, a Society including men of science of all the Australian colonies and some distinguished European naturalists, the object being to support biological stations in Australia. It is very gratifying to find so enlightened a sympathy with scientific progress developed, and that the different colonies are able to work together in so excellent a cause. We hope to refer shortly again to the constitution and aims of the Australian Biological Association.

\section{NOTES}

WE can only for the present express the deep regret with which we learn of the death, on the 9 th inst., of Prof. H. J. S. Smith, of the Savilian Chair of Geometry at Oxford, at the 